\title{
RECURSOS HUMANOS E RELAÇÕES DE TRABALHO: ALÉM DO SENSO COMUM
}

\author{
Por Allan Claudius Queiroz Barbosa \\ Professor da UFMG. Coordenador do Núcleo Interdisciplinar sobre Gestão em Organizações (Não) \\ Empresariais (Nig.one) da UFMG e do Observatório de Recursos Humanos em Saúde UFMG/SES-MG \\ E-mail: allan@ufmg.br
}

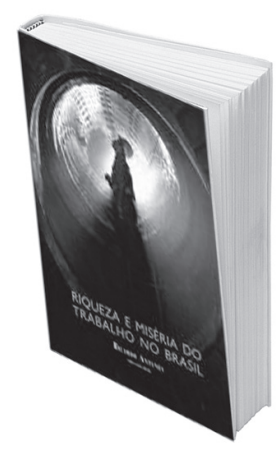

\section{RIQUEZA E MISÉRIA DO TRABALHO NO BRASIL}

De Ricardo Antunes (Org.)

São Paulo: Boitempo, 2006. 528 p.

O debate na Administração sempre teve a marca significativa de estudos ligados às relações de trabalho, quase sempre associados à gestão de recursos humanos. Em maior ou menor grau, é inegável seu papel na consolidação de uma linha analítica em um ambiente fortemente influenciado por uma abordagem, nem sempre convincente, pautada pela perspectiva humana, classicamente denominada relações humanas em suas múltiplas manifestações.

Essa importância ficou visível nas décadas de 1970 e 1980, que viram, em grande medida, o apogeu dos estudos com forte conotação sociológica no campo das relações de trabalho em diferentes áreas da Administração, com grande concentração em recursos humanos. A realidade das relações de trabalho indicou que, longe ser um espasmo circunstancial, uma linha analítica na Administração era reforçada.
Isso se deu tanto pelo fortalecimento das instâncias representativas dos trabalhadores como pelo esgotamento do modo de produção taylorista-fordista, com os decorrentes impactos sobre os empregados.

Paradoxalmente, os anos de $1990 \mathrm{e}$ as primeiras incursões no século XXI acabaram por evidenciar um relativo esvaziamento dessa instância no âmbito da Administração. Muitas são as explicações possíveis para tal situação, e um dos aspectos que pode servir como balizador a essa reflexão está pautado pela crise da sociedade do trabalho e seu impacto direto na gestão de recursos humanos. No caso brasileiro, isso fica evidente, e a fragilidade do ethos social reconhecendo direitos e conquistas históricas torna-se visível e serve como pista aos estudiosos. Isso sem falar no despreparo dos atores diretamente envolvidos nessa questão, na maioria das vezes habituados a um ambiente pouco afeito ao debate e às diferenças.

Mas, afinal, seria essa uma explicação adequada para justificar a perda de relevância, depois de quase duas décadas de transformações e mutações no espaço social e organizacional? $\mathrm{Ou}$ o espaço acadêmico das relações de trabalho na Administração está suficientemente maduro na sua tentativa de dar identidade e corpo definitivo ao seu construto teórico?

Sem entrar no mérito dessas dúvidas e independentemente do quadro atual, que ainda assim encontra uma aguerrida e consistente reflexão no âmbito da Administração, é inegável a necessidade de se buscarem abordagens em áreas do conhecimento que vêm sistematicamente sustentando, em alto grau, os estudos voltados às relações de trabalho e, por conseguinte, à gestão de recursos humanos.

Nessa linha, a obra organizada pelo 
professor Ricardo Antunes (Unicamp), intitulada Riqueza e miséria do trabalho no Brasil, deve ser saudada por todos os que fazem das relações de trabalho e da gestão de recursos humanos seu objeto de estudo. Inicialmente, por mostrar que é possível construir um entendimento interdisciplinar sobre o tema. Interdisciplinar, inter-regional e internacional, pela presença de pesquisadores espalhados pelo país e dada a importante contribuição do húngaro István Mészáros, filósofo atualmente radicado na Universidade de Sussex, Inglaterra.

Essa construção fica evidenciada pelas mais de duas dezenas de autores envolvidos nos 23 artigos, que se organizam em três partes: uma primeira, que apresenta uma discussão sobre o desemprego e a precarização do trabalho no Brasil; uma segunda, em que são apresentadas, por meio de estudos em diferentes empresas industriais, de serviços e das organizações artísticas, as chamadas formas da reestruturação produtiva; e uma terceira, em que são observados aspectos relacionados ao estado atual da representação sindical e da legislação trabalhista.

Com um olhar sobre o trabalho e conseqüentemente sobre o trabalhador, esta obra, pela variedade de setores produtivos abordados nos diferentes capítulos, joga luz tanto nos estudos voltados às relações de trabalho dentro da Administração quanto no papel dos gestores de recursos humanos em suas práticas. Gestores esses normalmente pressionados por um cotidiano que retira sua capacidade de ir além do mero ferramental. Ao serem forçados a leituras muitas vezes superficiais e de curtíssimo prazo, eles são impedidos, muitas vezes, de analisar os impactos inerentes a uma precarização, por exemplo, que perpassa todo o tecido organizativo, atingindo as dimensões concretas e simbólicas da gestão. Da mesma for- ma, fica difícil imaginar, nos gestores de recursos humanos, normalmente voltados ao imediatismo, que exige respostas e/ou soluções rápidas, maior aprofundamento sobre experiências bem fundamentadas como aquelas relatadas ao longo da obra.

Esse aspecto, aliás, joga luz sobre a formação daqueles profissionais que atuam em recursos humanos. Normalmente eles têm uma visão destituída de carga crítica e são embebidos de ferramental e objetividade fortemente instrumental. Daí os artigos deste livro servirem tanto ao estudo acadêmico de recursos humanos e relações de trabalho quanto aos gestores, pois permite que estes, caso queiram, ampliem seu escopo de entendimento dos aspectos que estão presentes nessa área do conhecimento aplicado.

O livro está longe de ser mera exacerbação ideologizada do tema, o que em certa medida marcou por muito tempo os estudos voltados a esta área dentro do campo da gestão de recursos humanos. Vai além e reflete a preocupação do organizador e dos diferentes autores em proporcionar informações e análises consistentes sobre uma área que padece de uma crise de identidade. Com efeito, relações de trabalho e recursos humanos têm se debatido nos últimos anos com uma forte dificuldade, tanto pelos modismos quanto pela força esmagadora de ações organizacionais que valorizam, em última instância, os resultados em um grau de exacerbação da individualidade jamais visto.

Como contraposição, é notável o esforço desta obra em proporcionar, quase como um mosaico, uma visão abrangente e crítica. Algo que tem sido tentado com muito esforço pelos pesquisadores e professores que atuam nesta área, dentro da Administração, preocupados em garantir consistência e qualidade.

E fica aqui, como fecho a esta resenha, uma pequena história, de que o professor Ricardo Antunes nem deve se lembrar. Foi na Cidade do México, em 1993, durante um Seminário Latino-Americano de Sociologia do Trabalho, quando, diante das escavações que se faziam na praça central da cidade, que mostravam ter ali existido antigas civilizações, por cima das quais diariamente milhares de mexicanos iam e vinham, ele disse: "Não é possível apagar os vestígios de uma civilização".

Sem dúvida, a obra de Ricardo Antunes serve como estímulo àqueles estudiosos da Administração que consideram possível manter o debate no campo das relações de trabalho em um nível elevado, impedindo que se apague o que está acumulado nessa área. E serve como ponto de reflexão. Afinal, a experiência deste livro é a experiência que justifica o próprio conhecimento, ampliado, diversificado e regionalmente espalhado. Que seja um exemplo e uma lição. E que os estudos sobre o trabalho na Administração recuperem o tempo perdido e permitam a construção de um, como bem chamou Ricardo Antunes no livro Inventário de pesquisa, que auxilie a comunidade envolvida no esforço de transformar as relações de trabalho e a gestão de recursos humanos em espaço privilegiado de reflexão e proposição de ações e/ou medidas voltadas aos indivíduos, às organizações e à sociedade.

O combate ao desacerto das relações de trabalho e da gestão de recursos humanos, ainda envolta em dificuldades para sua legitimação, e que insiste em dar voz aos oráculos e à "literatura de aeroporto", ao reconhecer estudos acurados e com base em evidências, ganhou um aliado importante no livro organizado por Ricardo Antunes. E devemos continuar tentando buscar reflexões no plano acadêmico e empresarial que extrapolem o senso comum. 